DOI: $10.31393 /$ reports-vnmedical-2021-25(4)-15

UDC: $616.127-005.8: 616.379-008.64]$ - 089.819-078

\title{
FEATURES OF ENERGY AND ADIPOKINE METABOLISM IN PATIENTS WITH ACUTE MYOCARDIAL INFARCTION AND TYPE 2 DIABETES AFTER PERCUTANEOUS CORONARY INTERVENTION
}

\section{Koteliukh M. Yu.}

Kharkiv National Medical University (4 Nauky Avenue, Kharkiv, Ukraine, 61022)

Received: September, 22, 2021; Accepted: October, 21, 2021

Annotation. The study of energy and adipokine metabolism indicators for the development and course of acute myocardial infarction (AMI) with comorbidity remains relevant. The aim of the study was to determine the content of energy and adipokine metabolism in patients with myocardial infarction and ST-segment elevation depending on the presence and absence of type 2 diabetes mellitus (DM) after percutaneous coronary intervention ( $P C l)$. The study involved examination of 60 patients with $A M I$ (Group 1) and 74 patients with $A M I$ and type 2 diabetes (Group 2). Each group was divided into 2 subgroups according to coronary artery (CA) stenting. The control group included 20 healthy individuals. Adropin, irisin, fatty acid binding protein 4 (FABP 4), C1q / TNF-associated protein 3 (CTRP 3) were determined by enzyme-linked immunosorbent assay. All patients underwent coronary angiography. Statistical processing of the results of the study was carried out using the software package "IBM SPPS Statistics 27.0". There was a decrease in the content of adropin, irisin and CTRP 3 and an increase in the concentration of FABP 4 on day 1 in Groups 1 and 2 compared with the control group ( $p<0.05)$. In Groups 1 and 2 on day 14 there was an increase in the concentration of adropin by $23.87 \%$ and $41.43 \%$, irisin by $56.59 \%$ and $11.11 \%$, CTRP3 by $11.59 \%$ and $20.01 \%$ compared to day 1 (p<0.05). The level of FABP 4 in Groups 1 and 2 decreased by $19.69 \%$ and $26.61 \%$ compared to day 1 ( $p<0.05)$. In Group 1, an inverse correlation was found between Syntax Score (SS) and adropin $(r=-0.432, p=0.01)$, irisin $(r=-0.478, p<0.01)$, CTRP $3(r=-0.473, p<0.01)$ and a positive correlation between SS and FABP $4(r=0.436, p<0.05)$. In Group 2, there was an inverse relationship between $S S$ and adropin $(r=-0.452, p<0.05)$, irisin $(r=-0.458$, $p<0.05)$, CTRP $3(r=-0.437, p<0.05)$ and the direct relationship between SS and FABP $4(F A B P 4(r=0.418, p<0.05)$. Thus, the peculiarities of the content of energy and adipokine metabolism indicators in patients with AMI with existing and absent type 2 diabetes before and after primary $C A$ stenting were studied.

Keywords: myocardial infarction, comorbidity, percutaneous coronary intervention.

\section{Introduction}

Cardiovascular diseases (CVDs) are a global problem of humanity requiring significant socio-economic costs. For many years, ischemic heart disease (IHD) has ranked first according to the World Health Organization (WHO). IHD mortality in 2019 was 8.9 million worldwide [18]. Acute myocardial infarction (AMI) is one of the leading causes of death in ischemic heart disease. Diabetes mellitus (DM) is one of the risk factors for AMI. In 2019, according to the WHO, diabetes mellitus (DM) became the ninth leading cause of death in the world and is the direct cause of 1.5 million deaths [19]. Type $2 \mathrm{DM}$ and AMI are very often combined in clinical practice.

Percutaneous coronary intervention (PCI) under comorbid conditions improves the prognosis in patients with $A M I$, reducing the development of early complications and increasing the annual survival of patients [7]. An urgent issue is the study of markers of energy homeostasis [13, 21] and adipokine system $[8,11]$ in AMI. An interesting direction is the study of the relationship between the condition of the coronary arteries (CA), energy and adipokines in patients with AMI and type 2 DM.

The aim of this study was to determine the content of energy and adipokine metabolism in patients with STsegment elevation myocardial infarction (STEMI) depending on the presence and absence of type $2 \mathrm{DM}$ after $\mathrm{PCl}$.

\section{Materials and methods}

The study involved 60 patients (Group 1) with STEMI and 74 patients with STEMI and type 2 DM (Group 2). The study was conducted from 01 September 2018 to 31 December 2020. The first and second groups were divided into subgroups depending on the presence and absence of myocardial revascularization. The first group was divided into 20 patients with STEMI without stenting (subgroup 1) and 40 patients with $\mathrm{PCl}$ (subgroup 2). The second group consisted of 22 patients with STEMI and type 2 diabetes without myocardial revascularization (subgroup 1) and 52 patients with $\mathrm{PCl}$ in the presence of $\mathrm{AMI}$ and type $2 \mathrm{DM}$ (subgroup 2). The control group included 20 healthy individuals. All patients were diagnosed with STEMI, diagnosed and treated according to European guidelines of cardiologists [9]. Diagnosis and treatment of type 2 diabetes was performed in accordance with the American Diabetes Association and the European Association for the Study of Diabetes $(2018,2019)[4,5]$.

The design of the study was approved by the Ethics Commission of Kharkiv National Medical University (Minutes №2 of 2 April 2018). All patients who participated in the study read and signed a voluntary informed consent to participate in the study.

Patients who did not undergo myocardial 
revascularization received a loading dose of $300 \mathrm{mg}$ acetylsalicylic acid and $300 \mathrm{mg}$ clopidogrel. In both groups, an additional loading dose of $300 \mathrm{mg}$ clopidogrel in $\mathrm{PCl}$ was administered in $26.1 \%$ of patients and $180 \mathrm{mg}$ ticagrelor in $73.9 \%$ of cases. All patients received $100 \%$ statins and $81.9 \%$ nitrates. In addition, all patients received low molecular weight anticoagulants for the first 8 days. Myocardial revascularization was not performed in $36.4 \%$ of patients due to anatomical difficulties for CA stenting, hospitalization of patients during the lost "reperfusion window" more than 24 hours after myocardial infarction and no signs of pain at the time of hospitalization, patient refusal from stent implantation.

In both groups, the levels of adropin, irisin, fatty acid binding protein 4 (FABP 4) and C1q/TNF-related protein (CTRP 3) were determined by enzyme-linked immunosorbent assay 1 day before percutaneous coronary intervention and 14 days after hospitalization using "Human adropin", "Human Fibronectin type III domain-containing protein 5", "Human FABP 4" (Elabscience, Houston, USA) and "Human CTRP 3" (Aviscera Bioscience Inc, Santa Clara, USA) reagents.

The severity of coronary atherosclerotic lesions was assessed by SYNTAX Score (SS) and classified [3, 14].

Statistical processing of the obtained data was performed using IBM SPPS version 27.0 (2020) software (IBM Inc., USA, license No. L-CZAA-BKKMKE). The studied parameters were evaluated for the normality of the distribution according to the Shapiro-Wilk test. Quantitative and qualitative variables were used in the statistical analysis. Qualitative data were presented as percentages; quantitative in the form of median and interquartile range (25 and 75 percentiles). The nonparametric Mann-Whitney ranking criterion was used to compare quantitative indicators between the two groups. When comparing the indicators between the three groups, the nonparametric Kruskal-Wallis test was used. The frequency of signs in the groups was compared using the Chi-squared test. Spearman's correlation was employed to determine the relationship between the indicators. The critical level of significance for testing statistical hypotheses in the study was 0.05 .

\section{Results}

Group 1 consisted of $91.67 \%$ men, $8.33 \%$ women, with an average age of $59.00(53.00 ; 65.00)$ years and Group 2 comprised $68.92 \%$ men, $31.08 \%$ women, average age $60.00(52.00 ; 66.25)$ years. Risk factors in Group 1 were as follows: hypertension - 100\%, smoking - 25\%, hypercholesterolemia - 65\%, body mass index averaged $23.7 \mathrm{~kg} / \mathrm{m}^{2}$. In Group 2, a similar structure of risk factors was found: hypertension $-100 \%$, smoking - 13.5\%, hypercholesterolemia - 68\%, body mass index averaged $28.9 \mathrm{~kg} / \mathrm{m}^{2}$. Patients of Groups 1 and 2 underwent coronary angiography, followed by a decision on CA stenting.

According to Table 1, all patients did not have a significant difference $(p>0.05)$ in the localization of $\mathrm{Ml}$ and angiographic
Table 1. Localization of myocardial infarction and coronary angiography indicators.

\begin{tabular}{|c|c|c|c|}
\hline Indicators & Group 1 & Group 2 & $\mathrm{p}$ \\
\hline Anterior wall & $28(46.67)$ & $33(44.59)$ & 0.81 \\
\hline Inferior wall & $11(18.33)$ & $11(14.86)$ & 0.60 \\
\hline Posterior wall & $21(35)$ & $30(40.54)$ & 0.51 \\
\hline \multicolumn{4}{|c|}{ Infarction-dependent artery } \\
\hline LCA trunk & $9(15)$ & $15(20.27)$ & 0.43 \\
\hline AIVB LCA & $20(33.33)$ & $30(40.54)$ & 0.39 \\
\hline CB LCA & $6(10)$ & $8(10.81)$ & 0.88 \\
\hline RCA & $25(41.67)$ & $21(28.38)$ & 0.11 \\
\hline Univascular lesion & $19(31.67)$ & $19(25.68)$ & 0.44 \\
\hline Bivascular lesion & $11(18.33)$ & $18(24.32)$ & 0.40 \\
\hline Multivascular lesion & $30(50)$ & $37(50)$ & 1.00 \\
\hline \multicolumn{4}{|c|}{ Angiographic characteristics } \\
\hline Syntax scale, in \%: mild <22 & $31(51.67)$ & $40(54.05)$ & 0.70 \\
\hline Moderate - 23-32 & $22(36.67)$ & $24(32.43)$ & 0.60 \\
\hline Severe $>32$ & $7(11.67)$ & $10(13.51)$ & 0.76 \\
\hline \multicolumn{4}{|c|}{ TIMI blood flow before myocardial revascularization } \\
\hline TIMI -0 & $38(63.33)$ & $41(55.41)$ & 0.36 \\
\hline TIMI -1 & $15(25)$ & $6(8.11)$ & 0.007 \\
\hline TIMI -2 & 7 (11.67) & $27(36.49)$ & 0.001 \\
\hline
\end{tabular}

Note: LCA = left coronary artery, AIVB - anterior interventricular branch, $\mathrm{CB}$ - circumferential branch, RCA - right coronary artery.

characteristics. Prior to primary stenting, coronary blood flow was assessed using the Thrombolysis in Myocardial Infarction (TIMI) flow grade scale: both groups were predominantly found to have TIMI-0 blood flow, while in Group 1 , TIMI-1 blood flow was more common in $25 \%(p<0.05)$, and in Group 2 TIMI-2 blood flow was more frequently found in $36.49 \%(p<0.05)$.

In group 1, the levels of adropin, irisin, CTRP3 decreased by $24.3 \%, 68.9 \%, 16.17 \%$ compared with the control group $(p<0.05)$. In Group 2, the content of adropin, irisin, CTRP3 was significantly reduced by $40.12 \%, 71.32 \%, 30.88 \%$ compared with the control group $(p<0.05)$, and the content of FABP 4 significantly increased compared to control group $(p<0.05)$ (Table 2). This indicates an imbalance in the energy and adipokine profile in patients with AMI. Concentrations of adropin and CTRP3 per day were significantly reduced in patients with AMI and type 2 diabetes (Group 2) compared with patients with AMI (Group 1) $(p<0.05)$. The content of irisin and FABP 4 did not differ between the groups ( $p>0.05)$.

In the follow-up of observation for 14 days in Groups 1 and 2 there was an increase in the content of adropin by $23.87 \%$ and $41.43 \%$, irisin by $56.59 \%$ and $11.11 \%$, CTRP3 by $11.59 \%$ and $20.01 \%$ compared with day $1 \quad(p<0.05)$. In Groups 1 and 2, the content of FABP 4 decreased by $19.69 \%$ and $26.61 \%$ compared with day 1 ( $p<0.05)$.

Energy and adipokine metabolism indicators were compared with existing and absent $\mathrm{PCl}$ in Groups 1 and 2 
Koteliukh M. Yu.

Table 2. Indicators of energy metabolism and adipokine system.

\begin{tabular}{|c|c|c|c|c|c|}
\hline \multirow{2}{*}{ Indicator, $p$ value } & \multicolumn{2}{|c|}{ Group 1} & \multicolumn{2}{|c|}{ Group 2} & \multirow{2}{*}{ Control group } \\
\hline & Day 1 & Day 14 & Day 1 & Day 14 & \\
\hline Adropin, $\mathrm{pg} / \mathrm{mL}$ & $17.85(10.42 ; 20.90)$ & $22.11(20.45 ; 22.49)$ & $14.12(9.44 ; 16.94)$ & $19.97(16.35 ; 20.99)$ & $23.58(20.86 ; 26.29)$ \\
\hline$p$ value & & ${ }^{* *}<0.001$ & $\#=0.001$ & $\begin{aligned} & * *<0.001 \\
& \#<0.001\end{aligned}$ & ${ }^{*}<0.001$ \\
\hline Irisin, $\mathrm{ng} / \mathrm{mL}$ & $2.05(1.49 ; 2.35)$ & $3.21(2.40 ; 3.48)$ & $1.89(1.49 ; 2.21)$ & $2.10(1.67 ; 2.42)$ & $6.59(3.91 ; 7.92)$ \\
\hline$p$ value & & ${ }^{* *}<0.001$ & $\#>0.05$ & $\begin{aligned} & * *<0.001 \\
& \#<0.001\end{aligned}$ & ${ }^{*}<0.001$ \\
\hline FABP $4, \mathrm{ng} / \mathrm{mL}$ & $9.65(8.36 ; 10.92)$ & $7.75(6.27 ; 8.62)$ & $10.07(9.13 ; 11.92)$ & $7.39(6.17 ; 8.69)$ & $4.25(3.46 ; 6.16)$ \\
\hline$P$ value & & ${ }^{* *}<0.001$ & $\#=0.05$ & $\begin{array}{l}{ }^{* *}<0.001 \\
\#>0.05\end{array}$ & ${ }^{*}<0.001$ \\
\hline CTRP 3, ng/mL & $\begin{array}{c}264.78(240.20 \\
302.20)\end{array}$ & $\begin{array}{c}295.48(282.45 \\
305.11)\end{array}$ & $\begin{array}{c}218.32(191.95 \\
268.68)\end{array}$ & $\begin{array}{c}262.01(225.32 \\
288.84)\end{array}$ & $\begin{array}{c}315.85 \text { (287.06; } \\
371.02)\end{array}$ \\
\hline$p$ value & & ${ }^{* *}<0.001$ & $\#<0.001$ & $\begin{array}{l}{ }^{* *}<0.001 \\
\#<0.001\end{array}$ & ${ }^{*}<0.001$ \\
\hline
\end{tabular}

Note: ${ }^{* *}-\mathrm{p}<0.05$ compared between days 1 and 14; \# - p <0.05 compared between Group 1 and Group $2 ;{ }^{*}-\mathrm{p}<0.05$ compared with the control group.

Table 3. Indicators of energy and adipokine metabolism, taking into account the presence and absence of PCI on day 14 .

\begin{tabular}{|c|c|c|c|c|}
\hline \multirow{2}{*}{ Indicator, p value } & \multicolumn{2}{|c|}{ Group 1} & \multicolumn{2}{|c|}{ Group 2} \\
\hline & Day 1 & Day 14 & Day 1 & Day 14 \\
\hline Adropin, $\mathrm{pg} / \mathrm{mL}$ & $21.32(15.69 ; 22.41)$ & $22.26(21.26 ; 22.70)$ & $15.06(11.20 ; 17.53)$ & $20.63(18.87 ; 21.45)$ \\
\hline$p$ value & ${ }^{*}=0.02 \#<0.001$ & $\#<0.001$ & ${ }^{*}<0.001$ & \\
\hline Irisin, $\mathrm{ng} / \mathrm{mL}$ & $3.07(2.17 ; 3.50)$ & $3.26(2.58 ; 3.73)$ & $1.60(1.44 ; 1.97)$ & $2.27(2.04 ; 2.57)$ \\
\hline$p$ value & * $=0.198 \#<0.001$ & $\#<0.001$ & $*<0.001$ & \\
\hline FABP $4, \mathrm{ng} / \mathrm{mL}$ & $6.96(6.05 ; 8.58)$ & 7.87 (7.19; 8.65) & $6.34(5.46 ; 6.96)$ & $8.08(6.85 ; 9.41)$ \\
\hline$p$ value & ${ }^{*}=0.196 \quad \#=0.08$ & $\#=0.774$ & ${ }^{*}<0.001$ & \\
\hline CTRP 3, ng/mL & $288.19(278.14 ; 301.39)$ & $301.84(298.62 ; 318.03)$ & 215.86 (204.29; 228.49) & $281.15(258.66 ; 292.70)$ \\
\hline$p$ value & $\#<0.001$ & * $<0.001 \#<0.05$ & * $<0.001$ & \\
\hline
\end{tabular}

Note: * $-p<0.05$ compared to the presence and absence of a stent; \# - $p<0.05$ in comparison between Group 1 and Group 2.

(Table 3). Patients in Groups 1 and 2 under conditions of myocardial revascularization were shown to have an increase in the level of adropin by $4.41 \%$ and $36.99 \%$, CTRP3 by $4.74 \%$ and $30.25 \%$. In Group 1, the content of irisin and FABP 4 had no significant difference ( $p>0.05)$, while in Group 2 the concentration of irisin increased by $41.88 \%(p<0.05)$ and the level of FABP 4 remained elevated compared to patients who did not undergo myocardial revascularization $(p<0.05)$ (Table 4). That is, in both groups the concentration of adropin and CTRP3 increased under stent implantation. However, this suggests that $\mathrm{PCl}$ improved adropin and CTRP3 levels in Groups 1 and 2. Changes in irisin and FABP 4 in patients with AMI under comorbid conditions were not associated with CA stenting, but may have a different cause.

Under the conditions of myocardial revascularization when comparing Groups 1 and 2, the level of adropin, irisin and CTRP3 significantly increased by $7.9 \%, 43.61 \%, 7.36 \%$ compared with Group $2(p<0.05)$. The concentration of FABP 4 did not change when comparing both groups $(p>0.05)$. In patients with AMI who did not have a stent implanted on day 14 (Group 1), the level of adropin, irisin and CTRP3 was significantly increased $(p<0.05)$ compared with Group 2 (Group 2). The level of FABP 4 did not change when comparing the two groups ( $p>0.05)$. That is, in Group 1 the markers of energy and adipokine profile were better than in Group 2. The study showed that the time course of FABP 4 concentration probably did not differ in both groups ( $p>0.05)$. Therefore, myocardial revascularization in Group 1 did not affect irisin and FABP 4 and the change was not due to stent implantation. It should be noted that changes in the concentration of irisin and FABP 4 in Group 2 were not associated with stent implantation, but occurred under conditions of correction of carbohydrate metabolism.

In patients of Group 1, a correlation was found between energy metabolism and SS (adropin ( $r=-0.432, p=0.01$ ), irisin $(r=-0.478, p<0.01)$ ), as well as between adipokine and SS (FABP $4(r=0.436, p<0.05)$, CTRP $3(r=-0.473$, $\mathrm{p}<0.01)$ ). Also in group 2 there was a relationship between energy metabolism and SS (adropin $(r=-0.452, p<0.05)$, 
Table 4. Comparative characteristics of energy and adipokine metabolism indicators by the degree of CA lesion day 1 .

\begin{tabular}{|l|c|c|c|c|c|c|}
\hline \multirow{2}{*}{ Indicator } & \multicolumn{3}{|c|}{ Group 1 } & \multicolumn{3}{c|}{ Group 2 } \\
\cline { 2 - 7 } & Mild & Moderate & Severe & Mild & Moderate & Severe \\
\hline Adropin, & 21.49 & 19.16 & 16.53 & 14.29 & 13.68 & 11.25 \\
$\mathrm{fg} / \mathrm{mL}$ & $(19.23 ; 24.14)$ & $(13.42 ; 22.85) \#$ & $(9.58 ; 9.95) \#$ & $(11.32 ; 17.76)$ & $(8.99 ; 14.22)$ & $(6.74 ; 17.62)$ \\
\hline Irisin, & 3.03 & 2.22 & 1.94 & 1.92 & 1.86 & 1.66 \\
$\mathrm{ng} / \mathrm{mL}$ & $(2.92 ; 3.98) \#$ & $(1.96 ; 3.04) \#$ & $(1.08 ; 2.22)$ & $(1.52 ; 2.21)$ & $(1.43 ; 2.21)$ & $(1.22 ; 2.19)$ \\
\hline FABP 4, & 9.34 & 9.77 & 11.60 & 9.54 & 9.74 & 10.46 \\
$\mathrm{ng} / \mathrm{mL}$ & $(7.71 ; 10.55)$ & $(9.18 ; 10.77)$ & $(9.07 ; 14.05)$ & $(8.65 ; 10.89)$ & $(8.48 ; 12.73)$ & $(9.18 ; 11.93)$ \\
\hline CTRP 3, & 282.10 & 244.87 & 247.41 & 235.96 & 210.42 & 201.55 \\
ng/mL & $(253.76 ; 315.28)$ & $(221.58 ; 288.78)$ & $(222.38 ; 299.76)$ & $(216.88 ; 290.44)$ & $(191.62 ; 265.69)$ & $(164.54 ; 272.24)$ \\
\hline
\end{tabular}

Note. \# - p<0.05 in comparison between Groups 1 and 2

irisin $(r=-0.458, p<0.05))$, between the adipokine system and SS (FABP $4(r=0.418, p<0.05)$, CTRP $3(r=-0.437$, $\mathrm{p}<0.05))$.

It was determined that when comparing Groups 1 and 2 , low levels of adropin were associated with moderate and severe CA lesions $(p<0.05)$ (Table 4). Irisin levels tended to decrease according to the severity of CA lesions in both groups ( $p>0.05)$.

\section{Discussion}

It was determined that patients with IHD and type 2 diabetes have different degrees of $C A$ lesion severity compared with patients with no type 2 diabetes. Patients with multivascular lesions require dynamic monitoring [10]. Therefore, it is important to identify the indicators associated with the severity of the lesion. According to the results of $\mathrm{G}$. D. Lopaschuk et al. (2010) in diabetes, the heart is more dependent on the oxidation of fatty acids for energy production and shows impaired glucose uptake and insulin signaling, whereas in heart failure there is a general violation of mitochondrial oxidative phosphorylation with increased dependence on glycolysis [12]. T. R. Altamimi et al. reported that adropin increased the activation of insulin signaling [1]. It is believed that the sensitizing effect of adropin to insulin is mediated by increased glucose oxidation due to activation of pyruvate dehydrogenase. According to the results of $M$. Ozturk et al. (2020), patients with STEMI have low adropin levels and a negative correlation with SS, which indicates the severity of coronary lesion [16].

M. Y. Ho and C. Y. Wang (2021) identified the mechanisms of action of irisin through the main pathways PI3K / Akt / eNOS, AMPK [6]. Authors G. Zhu et al. (2016) found that irisin not only directly regulates the number of endothelial progenitor cells, but can also act indirectly by regulating glucose and triglyceride metabolism [23]. According to the results of A. D. Anastasilakis et al. (2017) patients with AMI have low levels of circulating irisin [2]. The content of irisin has been shown to be associated with the degree of coronary stenosis, which indicates the main regulation of its secretion

\section{References}

[1] Altamimi, T. R., Gao, S., Karwi, Q. G., Fukushima, A., Rawat, S., Wagg, C. S., ... \& Lopaschuk, G. D. (2019). Adropin regulates in accordance with the adequacy of blood supply to the heart muscle. It should be noted that the more severe stenosis, the lower the level of irisin.

M. Obokata et al. (2018) found that in patients with AMI before the $\mathrm{PCl}$, the FABP 4 content was high and then gradually decreased when measured on days 1 and 3 [15]. An increase in FABP 4 compared with moderate coronary heart disease was observed in patients with severe coronary heart disease. FABP 4 was found to be a predictor of angiographically severe coronary heart disease.

Transforming growth factor beta (TGF- $\beta$ ) has been reported to be involved in ventricular remodeling, contributing to myocardial fibrosis. CTRP3 attenuates TGF- $\beta 1$-induced signaling and pathogenic remodeling after myocardial infarction [20, 22]. According to M. Sawicka et al. (2016) CTRP 3 levels are reduced in patients with AMI [17].

Conclusions and prospects for further research

1. The study showed that the indicators of energy and adipokine metabolism in Group 1 were better than in Group 2. It was found that in patients with $A M l$ in the presence and absence of type $2 \mathrm{DM}$, the content of adropin was associated with moderate and severe CA lesion. The concentration of irisin tended to decrease according to the severity of CA lesion in both groups.

2. After administration of $\mathrm{PCl}$, the concentration of adropin and CTRP 3 increased in both groups. Myocardial revascularization did not affect irisin and FABP 4 levels in patients with AMI (Group 1). It can be assumed that changes in these markers in patients with AMI and type 2 DM (Group 2) occur due to the stabilization of carbohydrate metabolism.

This study was subject to a number of limitations. First, the sample size was relatively small $(n=134)$, which should be increased in the future to confirm the conclusions. Second, because the study included only patients with STEMI depending on the presence and absence of type $2 \mathrm{DM}$, the assessment of the severity of CA lesion requires the study of patients with NSTEMI in the presence and absence of type 2 diabetes.

cardiac energy metabolism and improves cardiac function and efficiency. Metabolism: clinical and experimental, 98, 
37-48. DOI: https://doi.org/10.1016/j.metabol.2019.06.005

[2] Anastasilakis, A. D., Koulaxis, D., Kefala, N., Polyzos, S. A., Upadhyay, J., Pagkalidou, E., ... \& Mantzoros, C. S. (2017). Circulating irisin levels are lower in patients with either stable coronary artery disease (CAD) or myocardial infarction (MI) versus healthy controls, whereas follistatin and activin A levels are higher and can discriminate MI from CAD with similar to CK-MB accuracy. Metabolism: clinical and experimental, 73, 1-8. DOI: https://doi.org/10.1016/j.metabol.2017.05.002

[3] Calculator SYNTAX Score http://www.syntaxscore.com/

[4] Cosentino, F., Grant, P.J., Aboyans, V., Bailey, C.J., Ceriello, A., Delgado, V., ... Wheeler, D.C. (2020). 2019 ESC Guidelines on diabetes, pre-diabetes, and cardiovascular diseases developed in collaboration with the EASD: The task force for diabetes, pre-diabetes, and cardiovascular diseases of the European society of cardiology and the European association for the study of diabetes (EASD). Eur Heart J., 41(2), 255323. DOI: https://doi.org 10.1093/eurheartj/ehz486

[5] Davies, M. J., D'Alessio, D. A., Fradkin, J., Kernan, W.N., Mathieu, C., Mingrone, G., ... \& Buse, J. B. (2018). Management of hyperglycaemia in type 2 diabetes. A consensus report by the American Diabetes Association (ADA) and the European Association for the Study of Diabetes (EASD). Diabetologia, 61, 2461-2498. DOI: https://doi.org 10.2337/dci18-0033

[6] Ho, M. Y., \& Wang, C. Y. (2021). Role of irisin in myocardial infarction, heart failure, and cardiac hypertrophy. Cells, 10(8), 2103. DOI: https://doi.org/10.3390/cells 10082103

[7] Hrebenyk, M. V., \& Levchyk, О. І. (2018). Особливості перебігу післяінфарктного періоду у пацієнтів із коморбідністю, які перенесли перкутанне коронарне втручання [Features of the postinfarction period in patients with comorbidity who underwent percutaneous coronary intervention]. Здобутки клінічної і експериментальної медицини - Achievements of clinical and experimental medicine, 2, 42-47. DOI: https://doi.org/10.11603/18112471.2018.v0.i2.8955

[8] Huang, I. C., Hsu, B. G., Chang, C. C., Lee, C. J., \& Wang, J. H. (2018). High levels of serum adipocyte fatty acid-binding protein predict cardiovascular events in coronary artery disease patients. International journal of medical sciences, 15(12), 1268-1274. DOI: https://doi.org/10.7150/ijms.25588

[9] Ibanez, B., James, S., Agewall, S., Antunes, M. J., BucciarelliDucci, C., \& Bueno, H. (2018). 2017 ESC Guidelines for the management of acute myocardial infarction in patients presenting with ST-segment elevation: The Task Force for the management of acute myocardial infarction in patients presenting with ST-segment elevation of the European Society of Cardiology (ESC). European heart journal, 39(2), 119-177. DOI: https://doi.org/10.1093/eurheartj/ehx393

[10] Ivchyna, N. A. (2018). Особливості ураження коронарних судин у хворих на IXC [Features of coronary artery disease in patients with coronary heart disease]. Proceedings of the VIII International Scientific and Practical Conference International Trends in Science and Technology (December 25, 2018, Warsaw, Poland), 2, 24-26.

[11] Li, Y., Wright, G. L., \& Peterson, J. M. (2017). C1q/TNF-related protein 3 (CTRP3) function and regulation. Comprehensive Physiology, 863-878. DOI: https://doi.org 10.1002/ cphy.c 160044

[12] Lopaschuk, G. D., Ussher, J. R., Folmes, C. D., Jaswal, J. S., \& Stanley, W. C. (2010). Myocardial fatty acid metabolism in health and disease. Physiol Rev., 90, 207-258. DOI: https:// doi.org/10.1152/physrev.00015.2009

[13] Ma, C., Ding, H., Deng, Y., Liu, H., Xiong, X., \& Yang, Y. (2021). Irisin: a new code uncover the relationship of skeletal muscle and cardiovascular health during exercise. Frontiers in physiology, 12, 620608. DOI: https://doi.org/10.3389/ fphys.2021.620608

[14] Neumann, F. J., Sousa-Uva, M., Ahlsson, A., Alfonso, F., Banning, A. P., \& Benedetto, U. (2019). 2018 ESC/EACTS Guidelines on myocardial revascularization. European heart journal, 40(2), 87-165. DOI: https://doi.org/10.1093/eurheartj/ehy394

[15] Obokata, M., Iso, T., Ohyama, Y., Sunaga, H., Kawaguchi, T., Matsui, H., ... \& Kurabayashi, M. (2018). Early increase in serum fatty acid binding protein 4 levels in patients with acute myocardial infarction. European heart journal. Acute cardiovascular care, 7(6), 561-569. DOI: https://doi.org/ $10.1177 / 2048872616683635$

[16] Ozturk, M., Turan, O. E., Sebin, E., Ceyhun, G., Aksakal, E., Kalkan, K., ... \& Murat, B. (2020). An analysis on coronary artery disease severity with serum adropin level in patients with acute ST-segment elevation myocardial infarction. Sakarya Med J., 10(4), 623-628. DOI: https://doi.org/10.31832/ smj. 767212

[17] Sawicka, M., Janowska, J., \& Chudek, J. (2016). Potential beneficial effect of some adipokines positively correlated with the adipose tissue content on the cardiovascular system. International journal of cardiology, 222, 581-589. DOI: https:/ /doi.org/10.1016/j.ijcard.2016.07.054

[18] WHO Newsletter: 10 leading causes of death in the world. https://www.who.int/ ru/news-room/fact-sheets/detail/thetop-10-causes-of-death

[19] WHO Newsletter: diabetes. https://www.who.int/news-room/ fact-sheets/detail/diabetes

[20] Wu, D., Lei, H., Wang, J. Y., Zhang, C. L., Feng, H., Fu, F. Y., ... \& Wu, L. L. (2015). CTRP3 attenuates post-infarct cardiac fibrosis by targeting Smad3 activation and inhibiting myofibroblast differentiation. J Mol Med (Berl)., 93, 1311-1325. DOI: https://doi.org/10.1007/s00109-015-1309-8

[21] Zhang, S., Chen, Q., Lin, X., Chen, M., \& Liu, Q. (2020). A review of adropin as the medium of dialogue between energy regulation and immune regulation. Oxidative medicine and cellular longevity, 2020, 3947806. DOI: https://doi.org/10.1155/ 2020/3947806

[22] Zhao, M., Zheng, S., Yang, J., Wu, Y., Ren, Y., Kong, X., ... \& Xuan, J. (2015). Suppression of TGF- $\beta 1 /$ Smad signaling pathway by sesamin contributes to the attenuation of myocardial fibrosis in spontaneously hypertensive rats. PloS One, 10(3), e0121312. DOI: https://doi.org/10.1371/ journal.pone.0121312

[23] Zhu, G., Wang, J., Song, M., Zhou, F., Fu, D., Ruan, G., ... \& Pan, X. (2016). Irisin increased the number and improved the function of endothelial progenitor cells in diabetes mellitus mice. Journal of cardiovascular pharmacology, 68(1), 67-73. DOI: https://doi.org/10.1097/ FJC.0000000000000386

\section{ОСОБЛИВОСТІ ЕНЕРГЕТИЧНОГО ТА АДИПОКІНОВОГО ОБМІНУ У ПАЦІЄНТІВ ІЗ ГОСТРИМ ІНФАРКТОМ МІОКАРДА ТА ЦУКРОВИМ ДІАБЕТОМ 2 ТИПУ ПІСЛЯ ПЕРКУТАННОГО КОРОНАРНОГО ВТРУЧАННЯ \\ Котелюх М. Ю.}

Аннотація. Актуальним є вивчення маркерів енергетичного та адипокінового обміну на розвиток та перебіг гострого інфаркту міокарда (ГІМ) із коморбідністю. Метою роботи було визначення вмісту показників енергетичного та адипокінового обміну у пацієнтів із інфрарктом міокарда та елевацією сегменту ST залежно від наявності та відсутності иукрового діабету (ЦД) 2 типу після перкутанного коронарного втручання (ПКВ). Обстежено 60 пацієнтів на ГІМ (1 група) та 74 хворих із ГІМ та ЦД 2 типу (2 група). Кожна група була розподілена на 2 підгрупи відповідно до проведення стентування 
коронарних артерій (КА). До складу контрольної групи ввійшли 20 практично-здорових осіб. Адропін, ірисин, білок, що зв'язує жирні кислоти 4 (FABP 4), C1q/TNF-асоційований білок 3 (CTRP 3) визначали імунофрерментним методом. Усім пацієнтам проведена коронарографрія. Статистичне опрацювання отриманих результатів дослідження проведено за допомогою програмного пакета "IBM SPPS Statistics 27,0". Виявлено зниження вмісту адропіну, ірисину і CTRP 3 та зростання концентрації FABP 4 на 1 добу у групі 1 та 2 у порівнянні із групою контролю (p?0,05). У 1 та 2 групі на 14 добу відбувається зростання концентрації адропіну на 23,87\% та 41,43\%, ірисину - на 56,59\% та 11,11\%, CTRP3 - на 11,59\% та 20,01\% у порівнянні із 1 добою (p<0,05). Рівень FABP 4 у 1 та 2 групі зменшувався на 19,69\% та 26,61\% порівняно із 1 добою (p<0,05). У групі 1 визначено зворотний кореляційний зв'язок між Syntax Score (SS) та адропіном $(r=-0,432, p=0,01)$, ірисином $(r=-0,478, p<0,01)$, CTRP $3(r=-0,473, p<0,01)$ та позитивний кореляційний зв'язок між SS та FABP $4(r=0,436, p<0,05)$. У групі 2 спостерігався зворотний взаємозв'язок між SS та адропіном ( $r=-0,452, p<0,05)$, ірисином $(r=-0,458, p<0,05)$, CTRP $3(r=-0,437, p<0,05)$ та прямий взаємозв'язок між SS та FABP 4 (FABP $4(r=0,418, p<0,05)$. Отже, було досліджено особливості вмісту маркерів енергетичного та адипокінового обміну у пацієнтів із ГІМ із наявним та відсутнім ЦД 2 типу до та після первинного стентування КА.

Ключові слова: інфаркт міокарда, коморбідність, перкутарне коронарне втручання. 